\title{
An empirical investigation on factors influencing customer loyalty and their relationships with quality of services: A case study of insurance firm
}

\author{
Rostam Pourrahidi, Masoud Pour Kiani and Majid Jafari*
}

Management Group, Kish International Unit, Islamic Azad University, Kish, Iran

\begin{tabular}{|c|c|}
\hline$\overline{C H R O N I C L E}$ & A B S T R A T T \\
\hline $\begin{array}{l}\text { Article history: } \\
\text { Received August } 25,2013 \\
\text { Received in revised format } \\
19 \text { September } 2013 \\
\text { Accepted } 23 \text { October } 2013 \\
\text { Available online } \\
\text { November } 112013 \\
\text { Keywords: } \\
\text { Insurance firm } \\
\text { Customer loyalty }\end{array}$ & $\begin{array}{l}\text { In this paper, we present an empirical investigation to study the effect of various factors } \\
\text { influencing customer loyalty and quality of services on customer satisfaction and customer } \\
\text { loyalty. The proposed study is implemented in one of Iranian insurance firms by choosing a } \\
\text { sample of } 171 \text { randomly selected customers of this insurance firm. We use SERVQUAL } \\
\text { standard questionnaire to measure customer satisfaction. The study examines three hypotheses } \\
\text { associated with the proposed study using one-way t-student as well as path analysis, and the } \\
\text { results have confirmed all three hypotheses. The study also uses Freedman test to rank the most } \\
\text { important factors and detects that value was the most important issue followed by trust, } \\
\text { customer satisfaction, empathy, value and resistance to change. }\end{array}$ \\
\hline
\end{tabular}

Quality of services

SERQUAL

\section{Introduction}

During the past few years, we have seen tremendous competition among business owners to provide better products and services with lower prices and higher quality (Zeithaml et al., 1990). The competition has grown so rapidly that most firms try to do their best for customer retention as well as attempting to gain more market share (Wright et al., 1994; Dick \& Basu, 1994; Camarero, 2007; Rauyruen \& Miller, 2007; Kim and Yoon, 2004). However, one primary question is to find influencing factors on increasing customer loyalty and whether the present services could satisfy customers to remain loyal to firm's different services. Najafi et al. (2013) studied the dimensions of hotel service quality and evaluated relative importance of different factors. They also evaluated service quality of Tehran hotels in terms of guests' perspectives based on SERVQUAL model. They reported that the best overall service quality predictor was "tangibles" followed by "service supply", "problem solving", "assurance" and "empathy".

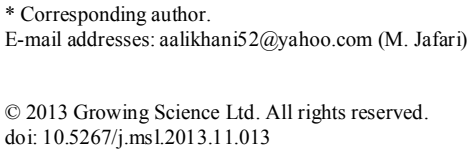


Aghaei et al. (2013) studied the relationship between service quality and customer loyalty in one of Iranian banks using SERVQUAL scale and a researcher-made questionnaire and examined service quality and customer loyalty, respectively. They reported a significant relationship between different aspects of service quality and customer loyalty in this particular branch of bank. Esmaeili et al. (2013) performed an investigation on the effects of loyalty on banking industry and reported that "satisfaction" was the most influential component influencing customer loyalty formation with an $87 \%$ diagnose coefficient.

Ghane et al. ( 2011 ) studied the relationship among e-satisfaction, e-trust, e-service quality and eloyalty in a case study of an Iranian e-banking and reported similar result. Asgarian (2013) performed an investigation on Iranian bank service quality in private sector by applying SEVQUAL method. The study reported that with the development of electronic commerce, internet banking could be considered as an alternative for developing, operating and offering bank services. Mouakket and Al-hawari (2012) presented findings about the antecedents of e-loyalty intention towards online reservation among 288 respondents in the United Arab Emirates. They examined the role of e-service quality, hedonic and utilitarian values, satisfaction, and subjective norms in motivating loyalty intention towards online reservation. They reported that e-service quality had a significant influence on hedonic and utilitarian values, which, in turn, influenced on customer satisfaction. Aydemir and Gerni (2011) studied the exporting firms' service quality perceptions and expectations about Turk Eximbank, the ECA in Turkey, by using SERVQUAL scale. They reported that there was a gap between exporting firms' service quality perceptions and expectations. Pourezzat et al. (2013) explained that the present market condition and embargo could damage quality of services in Iranian airline industry.

In this paper, we present a study to find important factors influencing the quality of the services in insurance industry. The proposed study first presents details of the study in section 2 . Section 3 presents the results of our survey and concluding remarks are given in the last to summarize the contribution of the paper.

\section{The proposed model}

The proposed model of this paper performs an empirical investigation on factors influencing customer loyalty and their relationships with quality of services based on Parasuraman et al. (1985, 1988, 1991) in a case study of an Iranian insurance firm named Alborz. The proposed study of this paper considers the following hypotheses,

First main hypothesis: There is a meaningful relationship between loyalty and customer loyalty. The first hypothesis consists of the following six sub-hypotheses.

1. There is a meaningful relationship between customer satisfaction and customer loyalty.

2. There is a meaningful relationship between customer value and customer loyalty.

3. There is a meaningful relationship between resistance to change and customer loyalty.

4. There is a meaningful relationship between customer empathy and customer loyalty.

5. There is a meaningful relationship between customer trust and customer loyalty.

6. There is a meaningful relationship between brand value and customer loyalty.

Second main hypothesis: There is a meaningful relationship between customer loyalty and factors associated with the quality of services.

1. There is a meaningful relationship between customer expectation and quality of services.

2. There is a meaningful relationship between perception value and quality of services.

3. There is a meaningful relationship between perception quality and quality of services. 
4. There is a meaningful relationship between customer complaints and quality of services.

5. There is a meaningful relationship between customer satisfaction and quality of services.

Third main hypothesis: There is a meaningful relationship between customer loyalty and quality of services.

1. There is a meaningful relationship between customer satisfaction and quality of services.

2. There is a meaningful relationship between customer value and quality of services.

3. There is a meaningful relationship between resistance to change and quality of services.

4. There is a meaningful relationship between customer empathy and quality of services.

5. There is a meaningful relationship between customer trust and quality of services.

6. There is a meaningful relationship between brand value and quality of services.

The sample size of the survey includes all customers of Alborz insurance firm, which is calculated as follows,

$N=Z_{\alpha / 2}^{2} \frac{p \times q}{e^{2}}$,

where $N$ is the sample size, $p=1-q$ represents the probability, $z_{\alpha / 2}$ is CDF of normal distribution and finally $\varepsilon$ is the error term. For our study we assume $p=0.5, z_{\alpha / 2}=1.96$ and $e=0.05$, the number of sample size is calculated as $N=171$.

\section{The results}

In this section, we present details of our findings on testing various hypotheses. Table 1 shows details of our survey on mean difference and t-student test associated with the first hypothesis.

Table 1

The results of mean-difference as well as t-student for the first hypothesis of the survey

\begin{tabular}{|c|c|c|c|c|}
\hline Variable & Mean difference & Sig & t-student & Status \\
\hline Customer satisfaction & 1.17 & 0.000 & 10.914 & Desirable \\
\hline Value & 1.0634 & 0.000 & 19.823 & Desirable \\
\hline Resistance to change & 0.6387 & 0.000 & 7.962 & Desirable \\
\hline Empathy & 1.1161 & 0.000 & 17.821 & Desirable \\
\hline Trust & 1.1508 & 0.000 & 18.782 & Desirable \\
\hline Brand value & 1.1877 & 0.000 & 18.899 & Desirable \\
\hline
\end{tabular}

As we can observe from the results of testing the first hypothesis, we realize that all components associated with the first hypothesis are within acceptable limits when the level of significance is one percent. In addition, the result of ANOVA test given in Table 2 indicates that there were some meaningful relationship between customer loyalty and its components. Therefore, we can confirm the first hypothesis.

Table 2

The summary of ANOVA test for testing the first hypothesis

\begin{tabular}{lccccc}
\hline & Sum of Squares & df & Mean of Squares & F-value & Sig. \\
\hline Regression & 37.640 & 6 & 6.273 & 37.875 & 0.00 \\
Residual & 22.692 & 137 & 0.166 & & \\
\hline Total & 60.332 & 143 & & & \\
\hline
\end{tabular}

Similarly, Table 3 shows details of our investigation on testing the second hypothesis. 
Table 3

The results of mean-difference as well as t-student for the second hypothesis of the survey

\begin{tabular}{|c|c|c|c|c|}
\hline Variable & Mean-difference & Sig & t-statistics & Status \\
\hline Customer expectations & 1.3277 & 0.000 & 12.367 & Desirable \\
\hline Perception value & 0.9349 & 0.000 & 13.299 & Desirable \\
\hline Perception quality & 0.9224 & 0.000 & 15.433 & Desirable \\
\hline Customer complaints & 0.8458 & 0.000 & 13.696 & Desirable \\
\hline Customer satisfaction & 1.0664 & 0.000 & 19.241 & Desirable \\
\hline
\end{tabular}

The results of the testing the second hypothesis, we realize that all components associated with the second hypothesis are within acceptable limits when the level of significance is one percent.

Besides, the result of ANOVA test given in Table 4 indicates that there were some meaningful relationship between customer loyalty and factors associated with quality of services. Therefore, we can confirm the second hypothesis.

\section{Table 4}

The summary of ANOVA test for testing the second hypothesis

\begin{tabular}{lccccc}
\hline & Sum of Squares & df & Mean of Squares & F-value & Sig. \\
\hline Regression & 37.640 & 6 & 6.273 & 37.875 & 0.00 \\
Residual & 22.692 & 137 & 0.166 & & \\
\hline Total & 60.332 & 143 & & & \\
\hline
\end{tabular}

Finally, the results of testing the last hypothesis of this survey are summarized in Table 5 as follows,

\section{Table 5}

The results of mean-difference as well as t-student for the third hypothesis of the survey

\begin{tabular}{|c|c|c|c|c|}
\hline Variable & Mean-difference & Sig & t-student & Status \\
\hline Physical appearance & 1.1678 & 0.000 & 17.606 & Desirable \\
\hline Reliability & 1.1268 & 0.000 & 11.739 & Desirable \\
\hline Responsibility & 1.149 & 0.000 & 10.619 & Desirable \\
\hline Assurance & 1.1092 & 0.000 & 18.243 & Desirable \\
\hline Empathy & 1.1075 & 0.000 & 10.943 & Desirable \\
\hline
\end{tabular}

The result of ANOVA test given in Table 6 indicates that there were some meaningful relationship between quality of services and customer loyalty.

Table 6

The summary of ANOVA test for testing the third hypothesis

\begin{tabular}{lccccc}
\hline & Sum of Squares & df & Mean of Squares & F-value & Sig. \\
\hline Regression & 37.500 & 6 & 6.250 & 20.382 & 0.00 \\
Residual & 41.398 & 135 & 0.307 & & \\
\hline Total & 78.898 & 141 & & & \\
\hline
\end{tabular}

The results of Table 6 also confirm the third hypothesis since all components are within acceptable limits when the level of significance is one percent.

We have also performed path analysis to examine various hypotheses of the survey and Fig. 1 summarizes the results of our investigation on path analysis for the first hypothesis. 


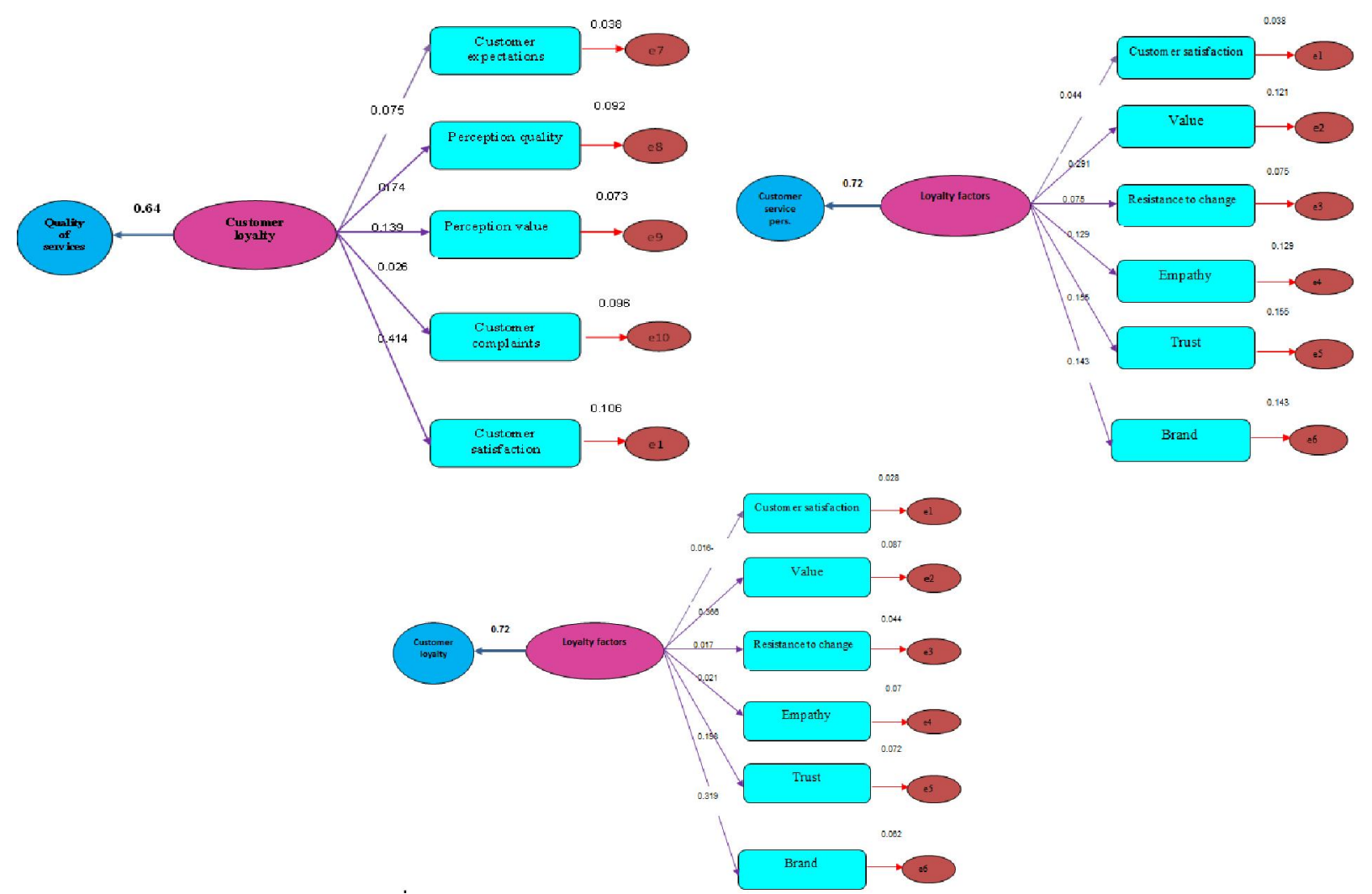

Fig. 1. The results of standard values of path analysis

Our investigation indicates that all components are statistically significant and confirm the effects of various factors. However, in order to find out the relative importance of each component, we need to perform Freedman test. Table 7 summarizes the results of our investigation.

Table 7

The summary of Freedman test

\begin{tabular}{lcccccc}
\hline Factor & Resistance to change & Value & Empathy & Satisfaction & Trust & Brand \\
\hline Value & 2.54 & 3.41 & 3.62 & 3.65 & 3.83 & 3.94 \\
\hline Chi-Square $=$ & $64.043(\mathrm{Sig} .=0.000)$ & & & & &
\end{tabular}

As we can observe from the results of Table 7, value is the most important issue followed by trust, customer satisfaction, empathy, value and resistance to change.

\section{Conclusion}

In this paper, we have presented an empirical investigation to study the effect of quality of services on customer satisfaction and customer loyalty. The proposed study has been implemented in one of Iranian insurance firms by choosing a sample of 171 randomly selected customers of this insurance firm. There were three hypotheses associated with the proposed study and it was found out that customer loyalty depended on quality of services in terms of various factors and value has been detected as the most important issue followed by trust, customer satisfaction, empathy, value and resistance to change.

\section{Acknowledgement}

The authors would like to thank the anonymous referees for constructive comments on earlier version of this paper. 


\section{References}

Aghaei, A., Mostafapour, M \& Rezaei, H. (2013). Investigating the relationship between service quality and customer loyalty: A case study of banking industry. Management Science Letters, 3(7), 2147-2154.

Asgarian, N. (2013). Bank service quality in private sector: Evidence from Iran. Management Science Letters, 3(2), 463-468.

Aydemir, S.D., \& Gerni, C. (2011). Measuring service quality of export credit agency in Turkey by using Servqual. Procedia - Social and Behavioral Sciences, 24, 1663-1670

Camarero, C. (2007). Relationship orientation or service quality? What is the trigger of performance in financial and insurance services? International Journal of Bank Marketing, 25(6), 406-26.

Dick, A. S., \& Basu, K. (1994). Customer loyalty: toward an integrated conceptual framework. Journal of the academy of marketing science, 22(2), 99-113.

Esmaeili, M., Nazarpoori, A \& Najafi, M. (2013). An investigation on loyalty formation model in ebanking customers: A case study of banking industry. Management Science Letters, 3(3), 903-912.

Ghane, S., Fathian, M. \& Gholamian, M.R. ( 2011 ). Full relationship among e-satisfaction, etrust, eservice quality and e-loyalty: The case study of Iran e-banking. Journal of Theoretical and Applied Information Technology, 33(1), 1-6.

Kim, H. S., \& Yoon, C. H. (2004). Determinants of subscriber churn and customer loyalty in the Korean mobile telephony market. Telecommunications Policy, 28(9), 751-765.

Mouakket, S., Al-hawari, M.A. (2012). Examining the antecedents of e-loyalty intention in an online reservation environment. The Journal of High Technology Management Research, 23(1), 46-57.

Najafi, S., Saati, S., Bighami, M \& Abdi, F. (2013). How do customers evaluate hotel service quality? An empirical study in Tehran hotels. Management Science Letters, 3(12), 3019-3030.

Parasuraman, A, Zeithaml, V.A, \& Berry, L.L.(1985).A conceptual model of service quality and its implications for future research. Journal of Marketing, 49 (4), 41-50.

Parasuraman, A, Zeithaml, V.A, \& Berry, L.L. (1988).SERVQUAL: a multiple-item scale for measuring consumer perceptions of service quality. Journal of Retailing, 64 (1), 12-40.

Parasuraman, A, Zeithaml, V.A, \& Berry, L.L. (1991). Refinement and reassessment of the SERVQUAL scale. Journal of Retailing, 67(4), 420-450.

Pourezzat, A.A., Hassanzadeh, H.R., \& Ghassemi, R.A. (2013). The reduced profiteering quality as a cause of sanction in the airline companies of Iran (The Case of Zagros Airline Company). Procedia - Social and Behavioral Sciences, 81(28), 576-583.

Rauyruen, P., \& Miller, K. E. (2007). Relationship quality as a predictor of B2B customer loyalty. Journal of business research, 60(1), 21-31.

Wright, P.M, McMahan, G.C, \& McWilliams, A.(1994). Human resources and sustained competitive advantage: a resource-based perspective. International journal of Human Resourse Management, 5(2), 310-326.

Zeithaml, V.A, Parasuraman, A, \& Berry, L.L. (1990). Delivering Quality Service: Balancing Customer Perceptions and Expectations. New York, NY: The Free Press. 